\title{
Bbítuary
}

\section{Sir Gordon Gordon-Taylor}

SIR GORDON GORDON-TAYLOR, graduate Medicine: he was a frequent and K.B.E., C.B., M.A.(Aberd.), B.Sc., M.S. welcome visitor at our Office, and also at the (Lond.), F.R.C.S. (Eng.), Hon. F.R.C.S.E., Hon. F.R.C.S.I., Hon. F.R.A.C.S., Hon. F.R.C.S.(Cana d a), Hon. F.A.C.S., Hon. Sc.D. (Cantab.), Hon. M. D. (Athens), Hon. L L. D. ( Me 1 bourne and Toronto), VicePresident, Royal College of Surgeons of England. It is with the deepest sorrow that we have to record the tragic death, after a road accident, of our distinguished and

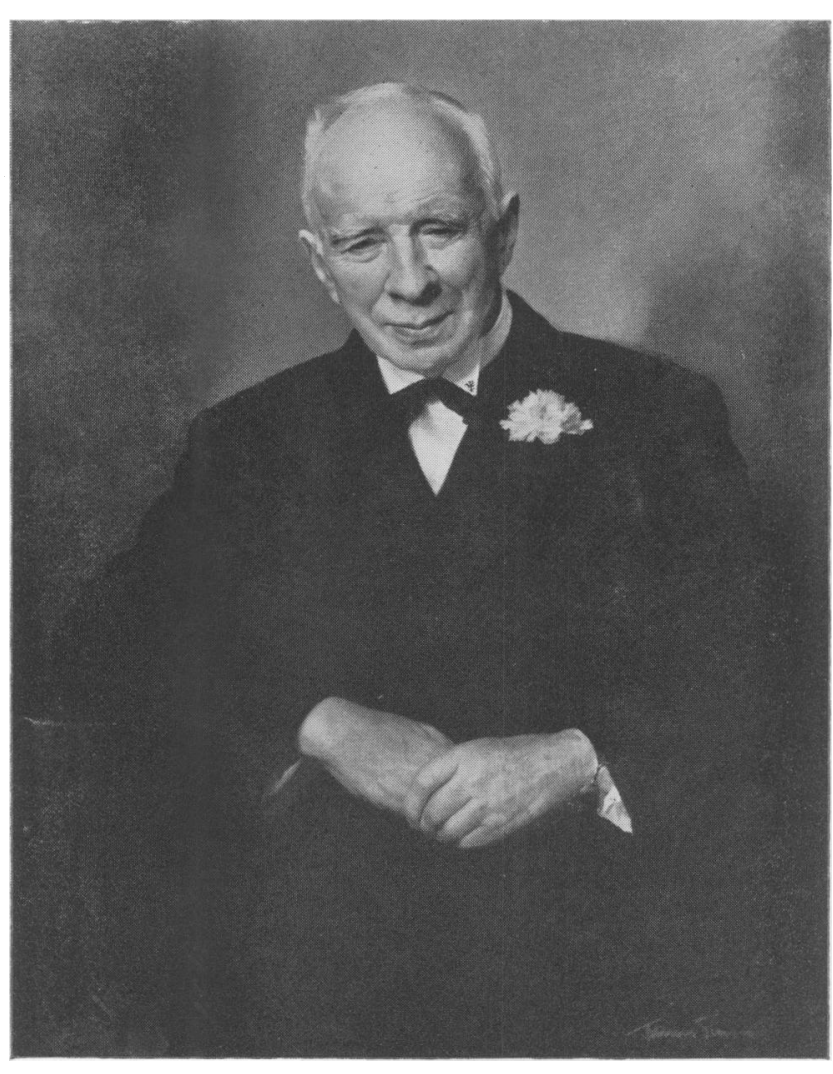

From the Portrait by James Gunn, A.R.A. dinners of the Executive Committee and Editorial Board, at which his suggestions and advice were always helpful and practical. His reputation as one of the leading surgeons of the United Kingdom was world-wide; his pioneer work has been recognized and honoured in every centre of the medical world. To all of us in the Fellowship he will still abide, even in death, as much beloved President. G-T., as he was affecone of our dearest friends. tionately known to all of us, was far from being a mere figure-head of the Fellowship of Post-

'Quamquam est subito ereptus, vivit tamen, semperque vivet'.

Maurice Davidson 